\title{
原琵論文
}

\section{霞ヶ浦妙岐ノ鼻湿原における 水位変化亡水循環}

\author{
中田 達1）塩沢 昌 1）吉田貢士 2) \\ 1) 東京大学大学院農学生命科学研究科 \\ （下113-8657 東京都文京区弥生1-1-1） \\ 2) 茨城大学農学部

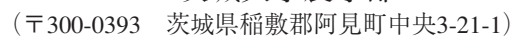

\begin{abstract}
氾濫源や河岸湿原は, 高い生物多様性と水質保全機能を持つとされるが，これにかかわる水位変化と河川との間の 水交換を調べた研究は少ない. 本研究は, 霞ヶ浦最大のヨシ原である妙岐ノ鼻湿原において水位の空間的分布と時間 変化を年間観測した結果，次の3段階のメカニズムによって水位変化が生じることを明らかにした．1）霞ヶ浦の水位 が湿原地盤高を超えると湿原内に河川・湖から水が流入し, 湿原全体が冠水する洪水ピーク時には湿原内の水位は 湖・河川に一致し, 湿原水位は湖の水位で決まる，2）その後，水位が河岸以下に低下すると，湖の水位が速やかに 低下しても湿原内の水位は緩やかに逓減し，また，湿原内の地形・標高により水位低下速度に差が生じる．3）さら に, 湿原水位が地盤高を下回ると, 蒸発散のみで水位低下が生じるが, 地下水面が土中のために水位低下速度は速く なる．氾濫時における水収支から，2006年における湿原と湖・河川との間の水の流入・流出の水交換の量を求めたと ころ, 増水時の湿原水位上昇において河川からの水の浸入が $58 \sim 78 \%$ を占め, 4回の汇濫による流入 ・流出量はほ ぼ年間の降雨量に匹敵する $1300 \mathrm{~mm} ゙$ あった。この汇濫時の湿原と河川との間の水交換が物質交換をもたらし, 湿 原の水質と生態に影響すると推察される.
\end{abstract}

キーワード : 河岸氾濫原, 霞ヶ浦, 水循環, 氾濫, 比浸出量

\section{I 、はじめに}

近年，1971年のラムサール条約や2002年に策定さ れた新・生物多様性国家戦略にみられるように, 国 内外で湿原の機能や価值が注目されている。汇濫源 や河岸の湿原はその独特の自然環境から高い生物多 様性を有し, 水質保全や洪水緩和の機能を有する点 でも重要な自然の構成要素である。土地利用別にエ コシステムサービスを貨幣価值で試算した報告によ れば, 湿原（特に沼沢・氾濫源）がきわめて高く評 価されている (Costanza et al., 1997).

しかし, 湿原は周囲の環境の変動によって大きな影 響を受け，劇的に生態系が変化する危険性を有してい る. 特に水環境に対する応答は顕著であり, 湛水深, 湛水期間の変化が植生群落の分離をもたらした例が報 告されている (Michelle and Margaret, 2000 ; 内田ら, 1999)。また, 沼沢や汇濫源での植生に対する栄養塩 の主な供給源は, 降雨と汇濫時に流入する水である. 汇濫時の流入水に含まれる窒素などの栄養塩濃度が
湿原における優占植生種の選択に大きな影響を及ぼ す。すなわち, 特定の条件下でのみ生存できる固有 種や絶滅危惧種を保護する上で, 水環境や気象, さ らには人間とのかかわりなど, 周囲の環境を把握し ておくことは不可欠である.

河川水の流入がある湿原は水質浄化機能を有する とされており, 洪水によって運ばれる懸濁態物質の 沈降や, 土潩の還元状態によって活性化される脱窒 などの機能を持つ(岡田, 1994 ; 細見, 1994). 廃水 処理を目的とした人口湿原の窒素除去能力の研究で は, 有機態炭素が十分に供給されていれば, 処理排 水中の高濃度の窒素の多くを除去可能であった (Gersberg et al., 1983; 北詰ら，1998).これに対し て, 自然湿原を対象として窒素収支を定量した研究 は, 氾濫源に扔いて洪水時に河川の自然堤防を越え る水量を推定し窒素収支を試算した例が挙げられる (Andersen, 2004）ものの, 少ない. 自然湿原では, 流入・流出する水量と窒素量を把握することが難し 
いためであろう.

霞ヶ浦は湖面積 $220 \mathrm{~km}^{2}$ を有し, 琵琶湖に次ぐわ が国第二の湖で, 首都圈に扮ける水資源の安定確保 に重要な役割を果たしている。しかし，1970年代か らの水質問題は解決には至っておらず，畜産や生活 系排水などの負荷源対策とともに自然の浄化機能を 活用しようとする試みもなされつつある（田渕, 2005)。霞ヶ浦湖岸のヨシ原は100年前には湖岸のほ ぼ全域に分布していたが，洪水被害防止のためのコ ンクリート護岸工事や水資源開発に伴う湖の管理水 位の上昇で，現在はそのかなりの部分が失われてい る(小沼・池田, 1999).

本研究で対象とする妙岐ノ鼻湿原は, 霞ヶ浦最大の ヨシ原として，国土交通省による「河川水辺の国勢調 査」などにおいてその生態系が注目されてきた。しか し現在，湖の管理水位の上昇による影響が心配され， 希少種の生育可能な植生群落であるヨシーカモノハシ 群落 (Phragmites- Ischaemum aristatum communities) が後退するなど, ここ数年で植生の変化が進行して いる，湿原内の植生群落の分布には, 霞ヶ浦の水位 上昇時に湿原に流入する河川水が影響している可能 性がある。

また，妙岐ノ鼻湿原においては，氾濫時における 湿原と湖（河川）との間の水の流入・流出が, 水に よって運搬される窒素など栄養塩の物質交換をもた らし，湿原の物質収支に重要な役割を担っているこ とが想定される。そこでまず本報では，湿原内の多 点での通年にわたる水位観測から湛水状況を知ると ともに, 汇濫時の水位分布と変化をモニタリングし, 水位と水循環の詳細を明らかにすることを目的とし た。とくに河川と湿原との間の水交換の量を明らか にすることが湿原での窒素除去などの水質浄化機能 を定量化する上で不可欠である，なお，湿原の水質 と窒素浄化機能については，別報で報告する。

\section{II . 妙岐ノ鼻湿原の概要}

\section{1. 妙岐ノ鼻湿原の地理的特徵}

妙岐ノ鼻湿原は茨城県霞ヶ浦 (西浦) 東南岸, 新 利根川河口左岸に位置する面積約 52 haに及ぶ高水 敷である(図一1).

地形的な特徵としては，大部分が高低差約 $30 \mathrm{~cm}$ 以下のきわめて平坦な土地で, 平均的な地盤高は湖 の平水時の水位とほぼ等しく, 利根川水系の基準標 高で表すと YP+1.1 m程度である (図一2). 霞ヶ浦

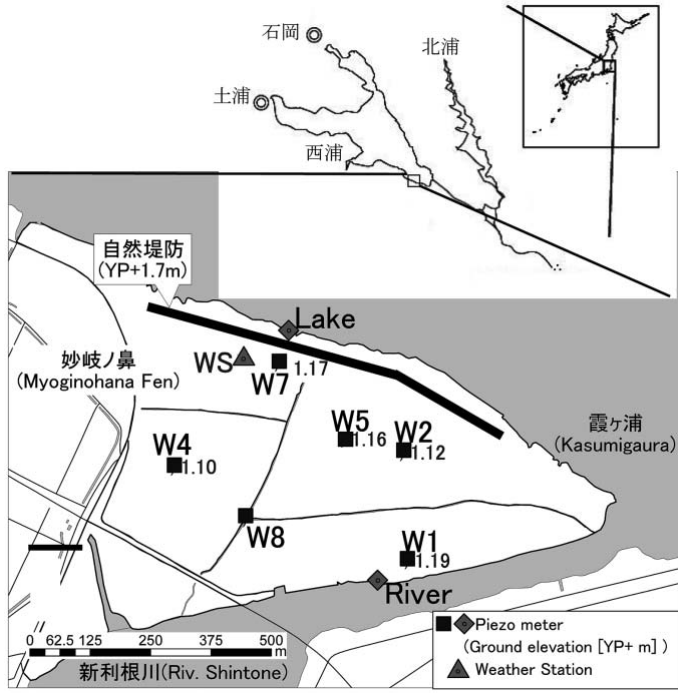

図 - 1 調査地および観測機器設置点

Fig. 1 Study site and water level observation points.

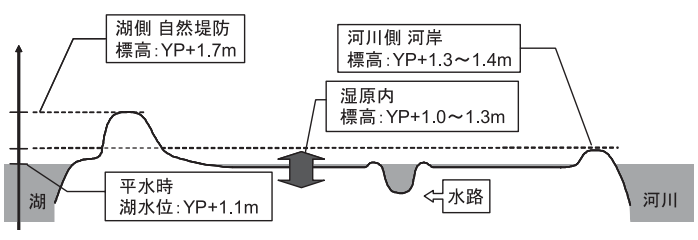

図-2 湿原の地形断面の模式図

Fig. 2 Vertical section of Myoginohana floodplain.

の水位は慣用的に利根川水系の河川改修基準面標高 YPを基準として表される（YP+0.84 m=海抜基準面） ため，本論でも水位や地盤高はYPを基準として表す。 湿原北岸の湖岸には自然堤防（YP+1.7 m程度）が 存在し湖との水の出入りを妨げているが，湿原東部 (先端部)の湖岸と河川側の護岸されていない部分に は自然堤防は見られない。湿原西端から南端の橋脚 部までは人工の堤防で護岸され，水の出入りは起こ らない。また，湿原内には，過去に湿原内の植生を 萱材として刈り取り・運搬していたときに掘削され た3本の水路が走り，東端で新利根川と通じている.

湿原内の優占植生種はヨシ (Phragmites australis) である。ヨシの下層にはカサスゲ (Carex dispalata), カモノハシ (Ischaemum aristatum var. glaucum) と いった丈の低い植生が生育し, 湿原東側（新利根川 河口部) にはヨシーカサスゲ群落 (Phragmites-Carex dispalata communities), 西側にはヨシーカモノハシ群 落 (Phragmites-Ischaemum aristatum communities) と いう植生分布になっている(図一3).1992年と1993 
年に行われた湿原内の植生調査によれば，ヨシーカ モノハシ群落の下層部は日光が当たりやすいことも あり，多くの保全上重要な植物が生育している（路 川ら，1992）。2002年の河川水辺の国勢調査におい て, 環境省レッドリスト・データブック（日本の絶滅 のおそれのある野生生物の種のリスト・データブッ ク；通称RDB）に記載されている14種, 茨城県RDB で17種の希少植物が確認された。

また，毎年春前にヨシやカサスゲの刚り取りが行わ れる湿原西側の一部微高地には，関東低地ではほとん ど見ることのできないミズゴケ (Sphagnum fimbiatum Wils）群落が存在する。これは刈り取られて日当た りの良くなった切り株の皿型微高地に腐食が堆積し て保水性を高め, 主として降水に涵養されてミズゴ ケが生育したと考えられる。

妙岐ノ鼻では過去に萱材として，ヨシ・カモノハ

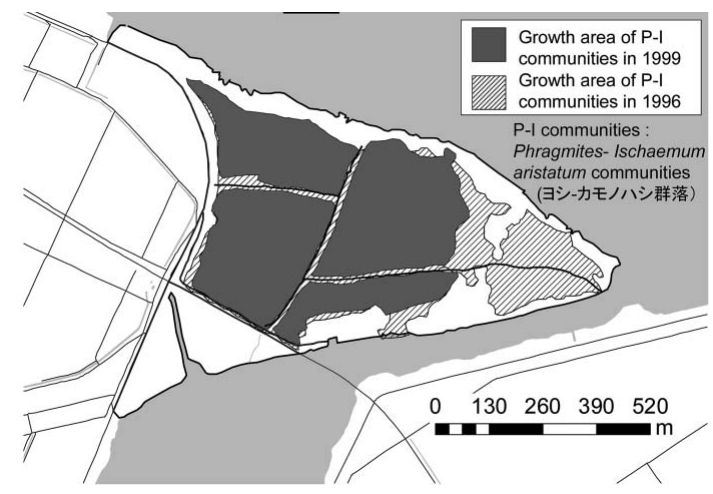

図－3 1996年から1999年におけるヨシーカモノハシ群 落の生育面積変化（2004年 水資源機構調査報 告より改編)

Fig. 3 Growth area change of Phragmites-Ischaemum aristatum communities between 1996-1999. (quoted from the research report by Japan water agency (2004))
シ等の刚り取りが行われ，萱としての質を維持する ため，野焼きといわれる火入れが行われてきた。刈 り取りは萱材の需要の低下とともに年々減少し, 現 在では湿原西側の一部でのみ行われている．野焼き は近年まで年に 1 回，3分の一から半分を冬季に火入 れしてきたが，2005年以降は行われていない。この カモノハシおよび希少植物の分布場所は，湿原の 河川から見て奥（西側）に位置し，湿原に侵入す る河川水の影響が及びにくいためではないかと考 えられる。

\section{2. 霞ヶ浦の水資源開発と妙岐ノ鼻湿原における 既往の調查}

1995年に霞ヶ浦開発事業が完成し, 湖水位の変動 範囲が変わることとなった。湖の計画管理水位は, 1995年に約 $15 \mathrm{~cm}$ 程度上昇され，それまで通年平均 してYP+1.1 mであった管理水位を夏季 $\mathrm{YP}+1.1 \mathrm{~m}$, 冬季YP+1.3 mとした。これは, 霞ヶ浦の水を各種 用水として利用するために農業用水需要期前の3月初 旬にYP+1.3 mの水位を目標として管理されている ためである。図ー4に国立環境研究所の霞ヶ浦デー夕 ベースを引用し，1992年から95年までの平均と96年 から2002年の平均の水位変化を示した。

この1995年の約 $15 \mathrm{~cm}$ 程度の水位上昇が植生に影響 を与えたとされており（水資源機構 2004；2005）, 湖 水位変更後のわずか数年で，希少種が存在するヨシー カモノハシ群落が大きく後退している（図一3）. 湿 原の地盤高と水位上昇後の湖の水位とはほぼ等しい 高さ $(\mathrm{YP}+1.0 \sim 1.3 \mathrm{~m})$ であり, 湖の水位が数 $\mathrm{cm}$ 上 昇しただけでも湿原への水の浸入は容易となったと 考えられる。しかし，湖の水位が湿原内水位に及ほ す影響に関しては調べられておらず，その空間的分 布と時間変化，および水位変化をもたらす湿原内の

\section{表 -1 水位計の地盤高, 平均水位, 地理的特徵}

Table 1 Ground elevation, average water level and geomorphologic features of water level observation points.

\begin{tabular}{c|c|c|c}
\hline 設置点 & $\begin{array}{c}\text { 地盤高 } \\
{[\mathrm{YP}+\mathrm{m}]}\end{array}$ & $\begin{array}{c}\text { 平均水位 } \\
{[\mathrm{YP}+\mathrm{m}]}\end{array}$ \\
\hline 湖 & & 1.17 & \multicolumn{1}{c}{ 地理的特徵 } \\
河川 & 1.17 & 湖の水位 \\
W1 & 1.19 & 1.22 & 河川(新利根川) の水位 \\
W2 & 1.12 & 1.25 & 河川沿岸. 地盤は高いが, 容易に水が流入 \\
W4 & 1.10 & 1.22 & 低層湿原の中央部 \\
W5 & 1.16 & 1.20 & 凹地. 付近にミズゴケが群生 \\
W7 & 1.17 & 1.17 & W2と隔てて植生遷移が進行 \\
水路 & $1 \mathrm{~W} 8)$ & & 自然堤防の内側で湖と隔てている \\
\hline
\end{tabular}




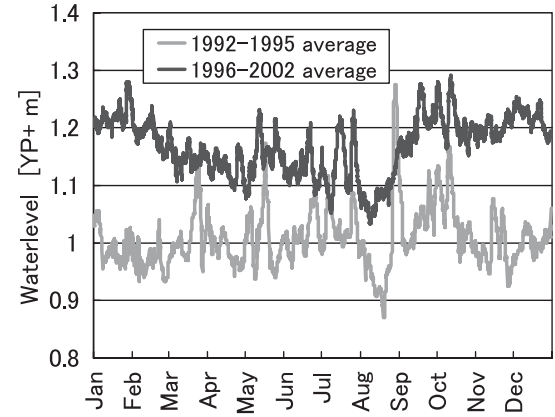

図-4 開発事業完成前後での湖水位の変化（国立環境 研究所霞ヶ浦データベースより筆者作成)

Fig. 4 Comparison of lake water level fluctuations between before and after the water resources development project. (quoted from Kasumigaura database by The national institute for environmental studies)

水の流れ（特に，湖の水位との関係）は不明である.

\section{III. 研究方法}

霞ヶ浦妙岐ノ鼻湿原に打いて，2006年4月より水位 と気象要素の観測を開始した。

\section{1. 水位観測}

湖, 新利根川, 水路と湿原内 5 点の計 8 点にピエゾ メーター水位計を設置した (図一1). 地中に打ち込 んだ塩ビパイプ $(\phi 5 \mathrm{~cm})$ 内に防水した圧力センサ (ハイネット社製，ゲージ圧）を入れたもので，測定 水圧を 10 分間隔でデータロガー（日置電機社製）に 記録した。一ヶ月に一回程度の現地調査時に, 各水 位計のパイプの頭を水位基準点として水面の高さを スケールで測定し, 圧力センサーの出力を水位に換 算した。干渉型GPSを用いた測量により，各水位計 の水位基準点と地盤の相対標高を正確に測定した. これにより，離れた水位計地点間の水位の標高差を 約 $\pm 1 \mathrm{~cm}$ の精度で観測することを可能にした。表一 1に各地点の地盤高と地勢的特徵, 年間の平均水位を まとめた。

\section{2. 気象観測および蒸発散量の推定}

湿原内に気象観測タワー（HOBO社製）を設置し, 気温, 相対湿度, 気圧, 風速, 日射量を 10 分間隔で 観測した。また，同位置に $0.2 \mathrm{~mm}$ 転倒マス雨量計を 設置し，10分積算での降雨量を測定した。

対象地の蒸発散は, 次のFAO-Pennman Monteith式 (Allen et al., 1998) を用いて, 日可能蒸発散量を計
算した．この可能蒸発散 $E T_{0}$ は，土壤水分が十分な時

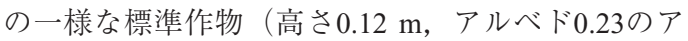
ルファルファ）を想定した標準蒸発散量である.

$$
E T_{0}=\frac{0.408 \Delta\left(R_{n}-G\right)+\gamma \frac{900}{T_{\text {avg }}+273} u_{2}\left(e_{s}-e_{a}\right)}{\Delta+\gamma\left(1+0.34 u_{2}\right)}
$$

ここで, $E T_{0}$ は標準作物における可能蒸発散量 $\left[\mathrm{mm} \mathrm{day}^{-1}\right], R_{n}\left[\mathrm{MJ} \mathrm{m}^{-2} \mathrm{day}^{-1}\right]$ は純放射, $G\left[\mathrm{MJ} \mathrm{m}^{-2} \mathrm{day}^{-1}\right]$ は地中伝導フラックス, $T_{a v g}\left[{ }^{\circ} \mathrm{C}\right]$ は平均気温, $u_{2}\left[\mathrm{~m} \mathrm{~s}^{-1}\right]$ は高さ $2 \mathrm{~m}$ における風速, $e_{s}[\mathrm{kPa}]$ は飽和 蒸気圧, $e_{a}[\mathrm{kPa}]$ は実蒸気圧, $\left(e_{s}-e_{a}\right)[\mathrm{kPa}]$ は蒸気 圧損失, $\Delta\left[\mathrm{kPa}^{\circ} \mathrm{C}^{-1}\right]$ は飽和蒸気圧曲線の勾配, $\gamma$

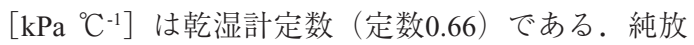
射 $R_{n}$ は実測した日射量をもとにFAOのガイドライン (Allen et al., 1998）に基づいて気象データから計算 した。地中への熱フラックス $G$ は1日を通じては $R_{n} に$ 比して十分に小さく, 日蒸発散に対しては無視でき る. 湿原は水分が十分にあるので，湿原の実蒸発散 量は，このE $T_{0} に$ 作物係数を乗じることで推定でき る.ヨシが群生した沼沢地の作物係数は1.0 1.2であ り,ここでは1.0とした.

\section{IV . 観测結果と水位変化のメカニズム}

本研究では，2006年4月18日から2006年11月10日 までの206日間の水位変化と気象デー夕を解析対象 とした.

\section{1. 降雨・蒸発散}

降雨量の観測結果と蒸発散量の計算結果を図一5に 示す。解析対象期間の総降雨量は995 mmであり,

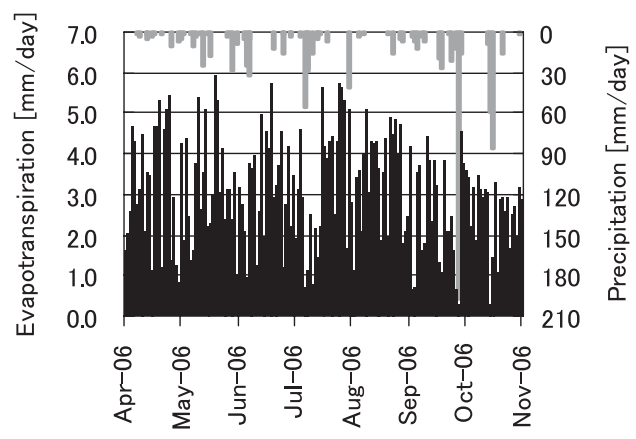

図 -5 蒸発散量および降雨量

Fig. 5 Evapotranspiration and precipitation. 


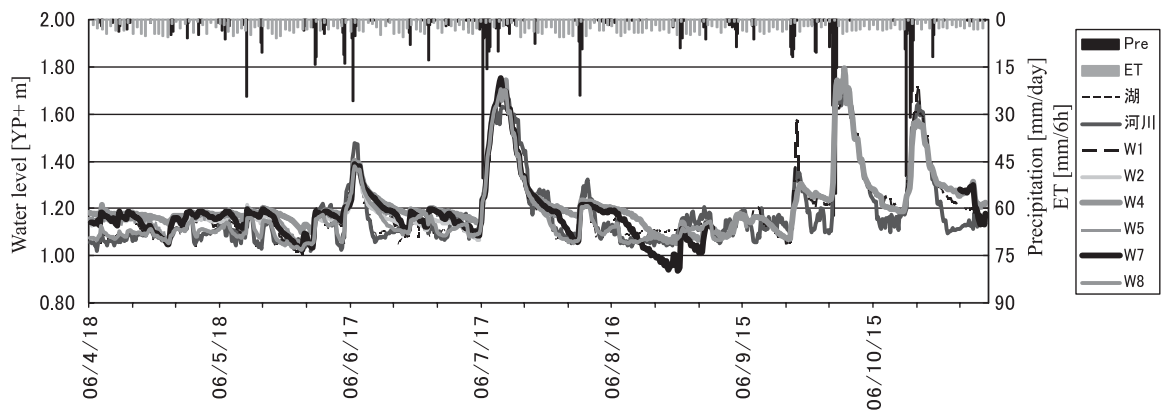

図－6 2006年の湿原内および湖・河川の水位変化

Fig. 6 Water level fluctuations in the Myoginohana floodplain, Lake Kasumigaura and the Shintone River in 2006.

過去10年における4月から 11 月の降雨量の平均值 907 $\mathrm{mm}$ よりも多少大きいが，ほぼ平年並みであった。観 測期間中で総降雨量 $50 \mathrm{~mm}$ を超す大きな降雨は6月 と7月に各1回，10月に2回の計4回あった。観測期間 中の蒸発散量の平均值は $2.9 \mathrm{~mm} \mathrm{day}^{-1}$, 観測期間全 体で601 mmであった。

\section{2. 水位変化の概要}

対象期間の湖, 新利根川, 湿原内の水位を図一6に 示す. 湖の水位の平均值 (mean) はYP+1.17 m, 中 央值（median）はYP+1.12 mであった。湿原内部は 平均值が湖よりも $5 \mathrm{~cm}$ ど高く，平均值は $1.21 \mathrm{~m}$ 前 後, 最頻値はYP+ 1.17 1.18 mとなった。標準偏差 は湿原内外ともにYP +0.15 程度で，これは平水時の水 位変動と考えてよい. 湿原全体を冠水させるような 大きな降雨に対しては, 湿原内の湛水状況は地盤高 や位置によって大きく異なった，河川に近く地盤高 も YP+1.19 m と調查地点の中で最も高いW1では全期 間中の $35 \%$ しか湛水しなかった。 それに対し, 周囲 が凹地で地盤高がYP+1.10 m と低いW4では期間中の $92 \%$ で湛水した.

\section{3. 土壤}

湿原内の土壤は, 地下 $20 \mathrm{~cm}$ 程度まで未分解のリ ターがある泥炭層をなしていた，既往の調査では， 地下 $10 \mathrm{~cm}$ までの部分での土性は粘土質シルト土壤 あるいは粘土であり，強熱減量は23～49\%である (水資源機構, 2005)。 それより下は, 地下 $70 \mathrm{~cm}$ 程度 まで粘土の多い層である。

本研究において，オーガーホール法（中野ら,1995) による現場透水試験を，湿原内6箇所において行った。 透水試験時の水位は地表から $1 \sim 5 \mathrm{~cm}$ である.オーガー ホール法は元々湿原の透水係数測定のために開発さ
れた透水試験法で，穴から瞬時に水を汲み上げた後 の水位回復曲線から飽和透水係数を算定するが，一 定の深さに不透水層がありその上部の透水係数が均 一であると仮定した解析法である。しかし実際，土 壤表層（地表から深さ5 10 cm程度）は未分解の植 物遺体と植物の根が多く透水性が高いが，その下部 の粘土混じりシルトの透水性は著しく低下する。こ の場合のオーガーホール法の測定值は, 土層全体の 平均透水係数であるが，そのオーダーは透水性の高 い表層の透水係数を反映する。得られた透水係数は, $3.1 \times 10^{-2} \sim 7.0 \times 10^{-3} \mathrm{~cm} \mathrm{~s}^{-1}$ であり，これは地表から $20 \mathrm{~cm}$ 程度までの表層の平均透水係数と考えられる. また, 深さ $40 \mathrm{~cm}$ の粘土混じりシルトの不攪乱土畩 をサンプリングして実験室にて変水頭法によって測 定したところ，飽和透水係数は $6.9 \times 10^{-4} \mathrm{~cm} \mathrm{~s}^{-1}$ と表 層より1〜2桁小さかった。このように表層のみ透水 性が高い土壤構造は高層湿原でも見られる湿原の特 徵である（塩沢ら，1995）。

\section{4. 氾濫時の水位変化メカニズム}

6月（図-7; 総降雨量 $71 \mathrm{~mm}$ ), 7月（図-8; 総 降雨量 $150 \mathrm{~mm}$ ), 10月に2回（図一9; 総降雨量226 $\mathrm{mm}$ および156 mm）の計4回の大きな降雨により， 湿原全体が氾濫し, 冠水した。総降雨量が100 mm を超える降雨はそのうち3回あったが，この時の湿原 内の水位上昇は $600 \mathrm{~mm}$ にもび, 湖や河川と同じ 水位になっている。これは, 氾濫時には湿原全体と 湖とが連続した水面となり，水位変化は湖の水位と 一体となっている様子を表している。水位上昇時に は湿原内に向かって河川から水の浸入があり，ピー クから水位降下時には湿原内から湖または河川に向 かって水の流出があることを示している。ささらは, 降雨の規模を問わず水位の最大值はYP+1.7 m前後 


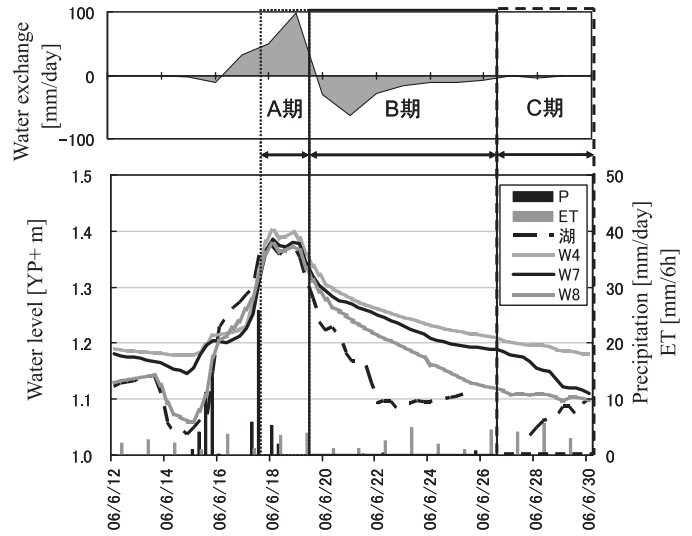

図一7 6月洪水における水位変化および水交換量

Fig. 7 Water level fluctuations and water exchange in June flood.

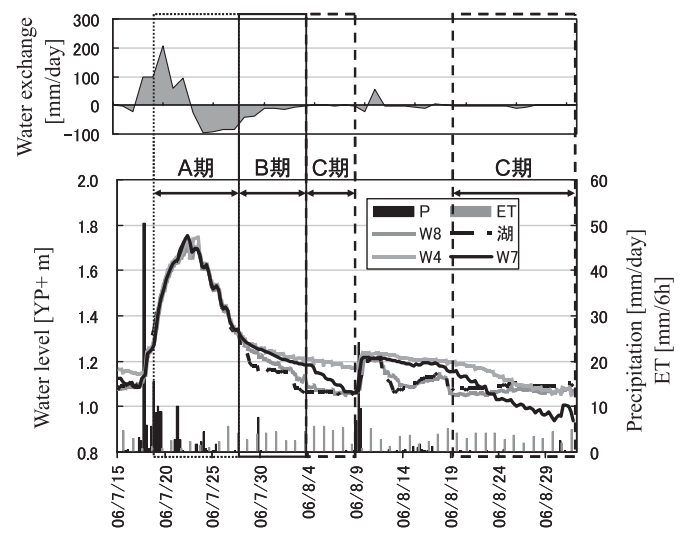

図－8 7月洪水における水位変化および水交換量

Fig. 8 Water level fluctuations and water exchange in July flood.

であり，10日前後で湖と河川の水位は下がりきり一 定值となる。

水位低下過程においては, 流出経路の違いにより 次の3つの期間に区別されることがわかった。

\section{1）洪水ピーク期}

洪水の水位ピーク時には, 河川・湖と連続した湛 水状態となり, 湿原内に水位差はなく湖の水位に一 致する。水位ピーク後しばらくは河川・湖の水位低 下に従う（図一7〜9中のA期間）。

\section{2）地表水流出期}

水位が $\mathrm{YP}+1.35 \mathrm{~m}$ 以下となると湿原内と河川・湖 とで低下過程に差異が現れる。このときの水位 $\mathrm{YP}+1.35 \mathrm{~m}$ は水際の河岸の地盤高であると考えられ る。この期間においては, 河川・湖と湿原で水位差 を生じる. 河川・湖の水位は霞ヶ浦の水門操作に支

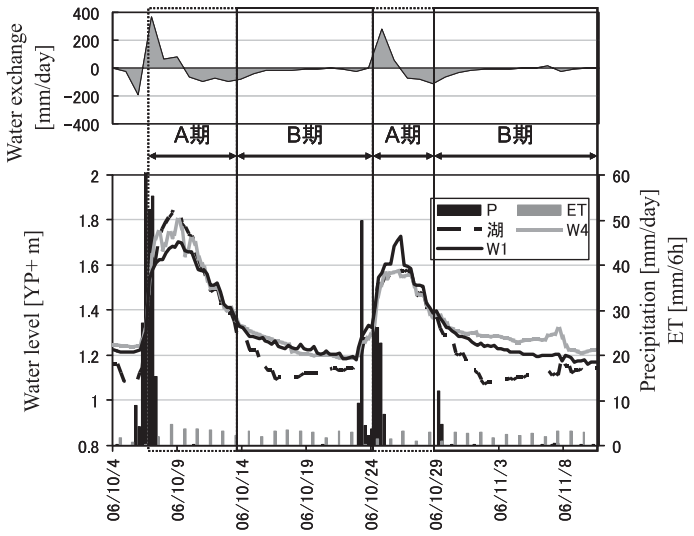

図－9 10月洪水における水位変化および水交換量

Fig. 9 Water level fluctuations and water exchange in October floods.

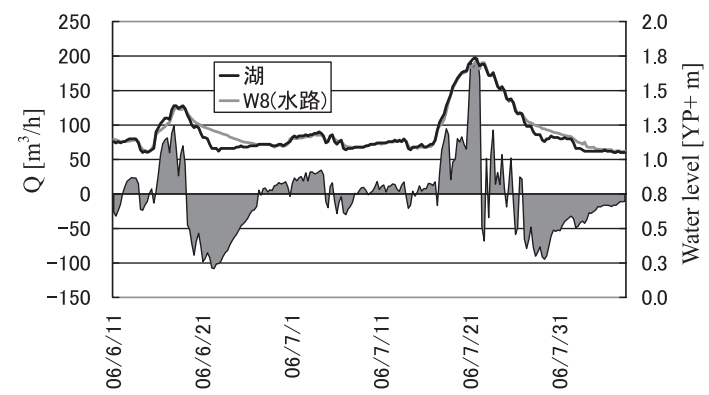

図一 10 水路を経由する水の流入量 - 流出量 (Qは湿原 への流入が正)

Fig. 10 Inflow and outflow volume via water channel. (Positive ordinate means Inflow to the floodplain)

配されて速やかに低下するが，湿原内では河川・湖 へと向かう地表水の流れに支配され, 水位低下は遅 れ，緩やかな低下曲線を描く (同, B期間)。湿原内 の水深はもはや湿原の大半を水没させるものではな くなり, 河川・湖へと向かう地表水の流れに対して 水理抵抗による水位差が生じる。湿原内でも場所に よる水位差が生じる。微高地などの凸部（観測点で いえばW1やW7）では地表水は低地に向かって流れ るため比較的速やかに水位低下し, 湛水しない地点 がパッチ状に現れはじめる。逆に周囲に比べ凹地に なっているW4では周囲から地表水の流れがあるため 湛水深の低下は緩やかである。この期間の湖と湿地 間の水交換は河川・湖への流出のみの一方的なもの である。

\section{3）乾燥期}

湿原内の水位が地盤高を下回ると, 水位低下の傾 きが大きくかつ直線的となった (同, C期間). 湿原 
内では湛水がなくなると水平方向の水の移動は表層 水の水移動に比べ極端に制限される。そのため乾燥 期に扔いては，湛水していない部分での水位低下は ほとんどが蒸発散によるものである。これについて は後述する，蒸発散による水位低下が進むと湖の水 位を下回る水位を示す地点も現れる。

\section{$V$ ．水収支の算定と流出期・乾燥期に 扣ける検討}

\section{1. 河川との水交換量の算定}

$100 \mathrm{~mm}$ 程度の雨に対してその数倍の湿原水位上 昇があることから，増水時の湿原内の水位上昇は主 として河川・湖からの水の浸入によって引き起こさ れることがわかる. 湖の水位が湿原の地盤と水位を 超えて上昇すると, 湖（河川）から湿原に水が侵入 し，その後，湖の水位が低下すると湿原から湖（河 川）に向かう流出が生じる。湖（河川）と湿原との 間のこの水交換は同時に, 水に含まれる物質の交換 をもたらすはずである．河川・湖との物質交換を考 える上で, 汇濫時の水の交換量を求める必要がある. そこで, 次の増水抒よび減水時の水収支式から湖 （河川）との間の流出入量を求めた.

$$
F=\Delta S-(P-E T)
$$

ここで， $\Delta S$ は水位変化による湿原内の貯留量変化, $P$ は降雨量, ETは蒸発散量である. Fは河川・湖と湿 原との間での水交換量と定義できる。この水交換が 生じるのは湿原が湛水状態の時なので $\Delta S$ は水位変化 に等しい。 $\Delta S$ を10分ごとの水位変化から求め, 水交 換量 $F$ 算出した。 Fが正ならば河川・湖から湿原へ の流入量, 負ならば湿原から河川・湖への流出量と なる.

図-7〜9上図の縦軸の正が湿原内部への流入量, 負が流出量である。水位のピークを境に流入から流 出へと変わっている．湿原内の水位上昇の $58 \sim 78 \%$ は河川・湖からの流入によるもので, 残りが湿原に 降る降雨によるものであることがわかった（表一2）. 2006年に生じた4回の汇濫による河川からの流入量は 約 $1300 \mathrm{~mm}$ となり，ほほ年間の降雨量に匹敵する。

氾濫時の河川からの水の流入がなければ, 湿原に は降雨以外に水の流入はなく, 大気経由での物質の 流入以外に物質の流入はないが，河川からの流入水 は水とともに水に溶解した栄養塩類等の物質を湿原 内に運搬する。そのため氾濫時の水交換量は湿原の
表 -2 各洪水期間の水収支

Table 2 Water balance in each flood.

\begin{tabular}{l|c|c|c|c}
\hline & 6月 & 7月 & 10月 (1) & 10月(2) \\
\hline Inflow $[\mathrm{mm}]$ & 179 & 510 & 300 & 310 \\
$P[\mathrm{~mm}]$ & 71 & 150 & 226 & 156 \\
Oufflow $[\mathrm{mm}]$ & 176 & 545 & 515 & 400 \\
ET $[\mathrm{mm}]$ & 105 & 81 & 51 & 40 \\
$\Delta S=$ Inflow+P-ET-Outflow & -31 & 34 & -40 & 26 \\
\hline
\end{tabular}

物質循環にとって重要な構成要素となる。湿原内の 脱窒による窒素除去は, 河川からの窒素流入なしに は機能せず，河川からの水に流入の大きさが湿原に 水質浄化（窒素除去）機能を与えるものである。ま た, 湿原の植生分布は, 河川側にはヨシが優占種で あるが河川からみて奥にはカモノ八シが多く（図一 3), この違いも, 河川から運搬される硝酸態窒素な どの栄養塩の供給が河川側には多く, 奥には届かな いためではないかと考えられ, 湿原の植物生態系に も影響していると考えられる。

\section{2. 水交換の経路}

上述の湿原と湖（河川）との水交換に扔いて, 湿 原内の人工水路が流入・流出の主たる流路となって いることが考えられる，水位上昇時や「地表水流出 期」には, 湿原内部の水路（図一1のW8地点）と河 口出口（湖水位）との間に水位差が生じている（図一 10). 洪水時の水位上昇時はW8地点の水位の方が湖 水位より低く湿原への流入が生じ, その後の水位低 下過程では湖の水位の方が低く湿原からの流出が生 じていることがわかる。この 2 点間の水面勾配からマ ニング式に基づいて水路を矩形断面と仮定して, 水 路からの流入・流出量を推定し, 図一10に示した。前 節に示した総流入および総流出に占める割合を求め たところ，6月の氾濫において流入の5，流出の 14 \%であり，7月では，流入の $4 \%$ ，流出の $17 \%$ とな り，ともにそれほど大きな割合ではなかった。河川 水位（および湿原水位）が低い時は水路が湿原と河 川（湖）との間の水の流れの主たる経路になると考え られる。しかし, 河川水位が湿原の河川岸地盤高 （YP+1.35 m）を超える時には河川岸の全面から河川 水の侵入とその後の排水が生じ，この時には湿原のほ ぼ全面が湛水下となり，水路が主たる流路ではなくな る。水路は河川水位が低い時にも水交換の流路とな り，とくに排水を速めているが，大きな水交換は水位 上昇がYP+1.35 mを超える氾濫時に生じるため, 年間 の水交換量に対する水路の存在の影響は小さい. 


\section{3. 乾燥期の水位・貯留量変化}

図一11は図一8の乾燥期（C期）の一部を拡大した ものである. 降雨が無く, 水位が地盤高を下回ると, 水位低下速度が大きく（図一11上図では平均して17 $\left.\mathrm{mm} \mathrm{day}{ }^{-1}\right)$ かつ一定な階段状になる。 さらにこの直 線的な水位低下には一日周期の階段状の水位低下が みられる。これを詳しくみるために，乾燥後期の8月 21日から23日を拡大したのが図一11下図である。水 位は日中の9:00から 15:00に大きく低下するが，夜間 には水位低下がない.この水位変化の特徵は湿原内 の何れの水位計でもみられる。これは水位低下が蒸 発散によって生じていることを示している，日射が あり蒸発散の盛んな日中に水位が低下し, 日射がな く蒸発散がほとんどない夜間には水位低下は生じな いのである。また日中黄っている日にも水位低下は ほとんど生じない。

蒸発散量が小さい夜間や量った日に水位低下が生じ ないことは，地下水を通した湖・河川との水の流出・ 流入があったとしても蒸発散量に比べて十分に小さい ことを示す証拠である。もしも，地下水を通した流 入・流出が大きければ，湿原の水位が地表面下になっ
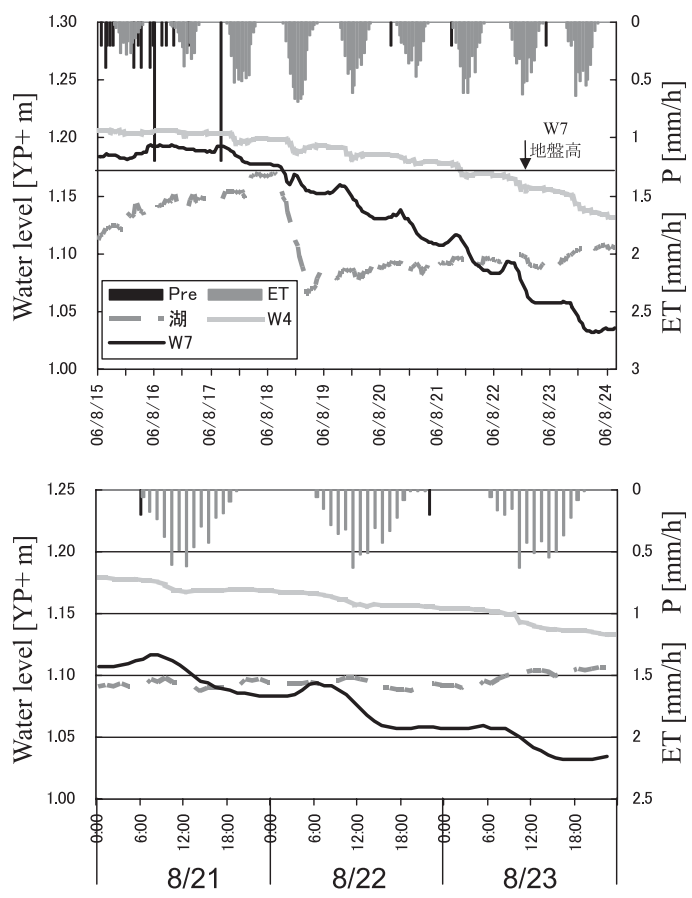

図-11 乾燥期前後の水位変化 (上), 乾燥後期の日単 位水位変化（下）

Fig. 11 Water level fluctuations from inundation to dry (upper), daily water level fluctuations in dry period (lower).
ても，湿原の水位は湖（河川）の水位の影響を受け, 湿原の水位が湖（河川）の水位よりも大きく低下する ことはないはずである，実際には，湿原の水位が地表 面下になると，湖（河川）の水位とは独立に変化する ようになり，蒸発散の大きい夏期の天気のよい期間に は，湿原の水位は湖（河川）の水位よりも低下しても なお，毎日ほぼ一定の速度で低下する。

地下水流の大きさは透水量係数（透水係数の深さ 方向への積分値）と動水勾配の積となる（ダルシー 則)．湿原の土壤表層（深さ5 $10 \mathrm{~cm}$ 程度）はリター 層で透水性が高いが，その下層は粘土分が多く透水 係数は表層に比ベオーダーが低い。このため, 湿原 水位は地表面下になるほど，水平方向に動水勾配が あっても水平流は生じにくくなる。湖（河川）との 水位差が一定のとき，地下水の動水勾配は湖（河川） との距離に反比例するので湖（河川）に近いほど湖 （河川）の水位の影響を受けやすい.しかし，たとえ

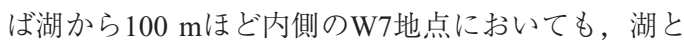
の水位差は最大でも $10 \mathrm{~cm}$ （図一11上図 8月18日 昼）程度であり，動水勾配は $1 / 1000$ 以下である。こ れに土壤の透水量係数を $10^{-2} \mathrm{~cm}^{2} \mathrm{~s}^{-1}$ と仮定すると単 位幅の地下水流量は $10^{-5} \mathrm{~cm}^{2} \mathrm{~s}^{-1}$ で, これが $100 \mathrm{~m}$ 長の 貯水量変化 $\Delta S$ をもたらすとして $\Delta S$ は $10^{-9} \mathrm{~cm} \mathrm{~s}^{-1}\left(10^{-3}\right.$ $\mathrm{mm}$ day $^{-1}$ ) であり, 蒸発散量に比べ無視できる. 本 湿原に扔いて全体として湖（河川）との間の地下水 流の影響がほとんどないのは，動水勾配が小さく透 水量係数も大きくないためであろう.

湿原水位が地表面下になると水位低下速度がそれ 以前の期間より大きくなるのは，水位が地表より上 の場合には水位低下 $(\Delta H)$ が貯留量変化 $(\Delta S)$ に 等しいが，水位が地表以下になると，地中での固層 の存在と不飽和層の水分保持のために, 水位低下に よる気相の増加分のみが貯留量変化になるためであ る。そのため地表面下に打ける貯留量変化は（3）式 のように表せる。水位変化と貯留量変化との比 $\Delta S$ / $\Delta H$ (比浸出量; Specific yield.) は, 水位が地表面 上であれば1であるが，地表面下（非湛水）になると 1 以下になる。( $\Delta S / \Delta H$ は有効間隙率と呼ばれるこ ともある). 水位が地表面下となる乾燥期の貯留量変 化 $(\Delta S)$ は専ら蒸発散量 $(E T)$ によると考えられ る。そこで $\Delta S=-E T$ そって $\Delta S / \Delta H$ を求めることが できる，以上をまとめると，次式のようになる。

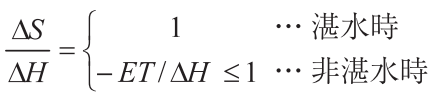




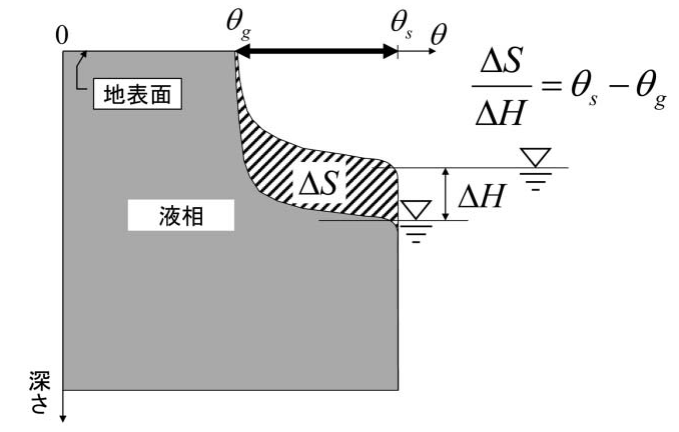

図-12 水位が地表面下に低下した場合の $\Delta S / \Delta H$ $\Delta H$ : 水位変化, $\Delta S$ : 貯留量変化 (ハッチ部 分） $\theta$ : 体積含水率, $\theta_{s}$ : 飽和体積含水率 地下水位が地表に近く, 不飽和層の $\theta$ が地下水 位の影響を受けるような湿原では， $\Delta S / \Delta H$ は地下水位に依存する。ただし, 表層の水分 量 $\theta_{g}$ が地下水位の影響を受けず, 地下水面上 の水分分布の形が変わらない場合は, $\Delta S / \Delta H$ は地表面における気相率 $\left(\theta_{s}-\theta_{g}\right)$ で表される

Fig. $12 \Delta S / \Delta H$ when the water level falls the subsurface

$\Delta H$ : change of water level in the floodplain,

$\Delta S$ : change of water storage (hatched area),

$\theta:$ volumetric water content,

$\theta_{s}:$ saturated water content

$\theta_{g}:$ water content at the subsurface

$\Delta S / \Delta H$ depends on the water table in the floodplain where the water table is near to the soil surface and the water content of the unsaturated layer $(\theta)$ is affected by the water table. However, if the water content of subsurface layer $\left(\theta_{g}\right)$ is not affected by water table, and the form of soil moisture distribution above the water table does not change, $\Delta S$ / $\Delta H$ is represented as gas phase rate in the soil surface; $\left(\theta_{s}-\theta_{g}\right)$.

8月の乾燥期に測定した $\Delta H$ と（1）式で求めたETの 比は，およそ0.2であった。すなわち， $\Delta S / \Delta H=0.2$ となった。この值が, 湿原の浅い地下水面上に形成 される不飽和層の気相率を表すものである (図一12). 水位が地表面下の場合の $\Delta S / \Delta H$ は, 水位変化 $(\Delta H)$ の伴う地下水面上の体積含水率変化 $(\Delta S)$ の比であ るが，地下水面上に静水圧分布を仮定し土壤が均一 だとすれば，水分分布は土壤水分特性曲線を表し， $\Delta S / \Delta H$ は近似的に地表面における気相率となる。た だ, 湿原地表面は普通の土壤とは異なり植生の根 と残渣が多く, 深さによって, また小さなサンプル スケールでは場所によって不均一で, その気相率を 直接測定することは困難である。この点で, 本研究 で蒸発散量と水位変化から得た $\Delta S / \Delta H=0.2$ は, $\Delta S$ と $\Delta H$ を湿原の広い面における長期の平均值として 得ており，信頼性が高いと言える。

\section{VI.まとめ}

湿原内に設置した水位計は $\pm 1 \mathrm{~cm}$ 程度の精度で相 対水位標高の分布を比較可能であり，これまで明ら かにされていなかった湖・河川と湿原内との水位変 化の違い，拈よび湿原内での地形による水位变化 . 湛水状況の差異を詳細に観測することができた.

洪水時から水位が低下するまでにおいては大きく 3つの流出過程があることがわかった。洪水のピーク 時には湿原全体が水没し湖の水位変化と一致する. その後, 水位が河岸の地盤高 $\mathrm{YP}+1.35 \mathrm{~m}$ 以下となる と湖と湿原内とで水位の差異が現れ，湿原鼻先部の 低地や湿原内を走る水路を介しての流出を生じる. また，微地形の違いにより湛水期間の違いが生じ， 地表露出面がパッチ状に現れるようになる。さらに 水位低下が進み，地盤高を下回る乾燥時には，昼間 の蒸発散量と土壤の特性值である比浸出量（約 $0.2 ）$ で水位変化が決まる。

増水時の湿原内の水位上昇は主として河川・湖か らの水の浸入によって生じ，その割合は水位上昇高 の58〜78％を占めた（残りは湿原における降雨）. 2006年6月から11月の間に生じた4回の汇濫による流 入量はほぼ年間の降雨量に匹敵し, $1300 \mathrm{~mm}$ と推定 された。このことから, 氾濫時の湿原と河川との間 の水交換は湿原内の物質交換に打ける主要な役割と して, 湿原内の水質に影響を与え, 湿原植生を決定 する要因の一つであると推察される。

\section{参考文献}

Allen RG, Pereira LS, Raes, D, Smith M. 1998. Crop evapotranspiration -Guidelines for computing crop water requirements. FAO Irrigation and drainage paper 56, UNFAO: Rome, 300pp.

Andersen HE. 2004. Hydrology and nitrogen balance of a seasonally inundated Danish floodplain wetland. Hydrological Processes 18: 415-434, DOI:10.1002/ hyp.1277.

Costanza R, d'Arge R, Groot R, Farber S, Grasso M, Hannon B, Limburg K, Naeem S, O’ Neill RV, Paruelo J, Raskin RG, Sutton P. 1997. The value of the world's ecosystem services and natural capital. Nature 387: 253-260, DOI:10.1038/387253a0.

Gersberg RM, Elkins BV, Goldman CR. 1983. Nitrogen removal in artificial wetlands. Water Research 17: 10091014.

細見正明 (1994): 湿地 (Wetland) の水質浄化機能<特集>: 内陸湿 地における自然浄化のメカニズムと浄化機能の積極的利用, 水環 境学会誌, 17 (3), pp.149-153.

北詰昌義・野口俊太郎・島多義彦・倉谷勝敏（1998）：人口湿地 による水質浄化, 用水と廃水, 40 (10), pp.51-57.

Michelle TC, Margaret AB. 2000. How do depth, duration and frequency of flooding influence the establishment of wetland 
plant communities? Plant Ecology 147: 237-250, DOI:10. 1023/A:1009875226637.

路川宗夫・西広淳・前田修 (1992): 霞ケ浦湖岸妙義の鼻の植物 相, 筑波の環境研究, 14, pp.71-78.

水資源機構 (2004): 平成15年度霞ヶ浦環境フォローアップ特定 地区調査報告書, pp.24-57.

水資源機構 (2005): 平成17年度新川地区他植物調査報告書, 85pp.

中野政詩・宮崎毅・塩沢昌・西村拓（1995）: 飽和透水係数測定 法, 土壌物理環境測定法, 東京大学出版会, pp.89-114.

岡田光正 (1994) : 湿地 (Wetland) の水質浄化機能<特集>: 湿地の

特性とその機能, 水環境学会誌, 17 (3), pp.142-148.
小沼秀㓲・池田宏（1999）: 霞ヶ浦土浦入り南岸におけるヨシ原 の縮小過程について, 筑波大学水理実験センター報告, 24 , pp.49-58.

塩沢昌 - 粕㴊辰昭- 宮地直道・神山和則 (1995): 一次元定常地 下水流動モデルによる美唄湿原の地下水位分布の解析, 農業 土木学会論文集, 176, pp.11-22.

田㴊俊雄（2005）：湖の水質保全を考える 霞ヶ浦からの発信, 技報堂出版, 194pp.

内田泰三・後藤美和子・丸山純孝 (1999): 湿性植物群落の成立 に影響を及ぼす諸環境要因の抽出, 草地学会誌, 45(3), pp.304-319.

（受付：2009年1月23日，受理：2009年8月6日）

\title{
Water Cycle and Water Level Fluctuations in Myoginohana Floodplain Located at Lakefront of Kasumigaura
}

\author{
Toru NAKADA ${ }^{1)}$ Sho SHIOZAWA ${ }^{1)}$ Koshi YOSHIDA ${ }^{2)}$ \\ 1) Graduate School of Agricultural and Life Sciences, The University of Tokyo \\ (1-1-1 Yayoi, Bunkyo, Tokyo 113-8657, Japan) \\ 2) Collage of Agriculture, Ibaraki University \\ (3-21-1, Chuo, Ami, Ibaraki 300-0393, Japan)
}

We investigated year-round water level fluctuations in Myoginohana floodplain, which is the largest reed wetland in Lake Kasumigaura and where there has been considerable focus on their functions such as biodiversity and water purification. As a result of having observed spatial and temporal changes of water levels in the floodplain and the lake, a series of three following mechanisms of water cycle was clarified. 1) In flood peak, the whole floodplain had same water level with the lake and the river. 2) In discharge period, when the water level in the floodplain got lower than the height of the floodplain edge, the water levels in the floodplain decreased more slowly whereas the water level of the lake fell immediately by the artificial operation of the water gate. And different reductions of water levels were observed within the floodplain caused by their topographic conditions. 3) Then if there was no longer inundation, only evapotranspiration let the water level decrease. Furthermore, water balance in each flood event was calculated to evaluate the volume of water exchange between the floodplain and the lake or the river. As the result, about 58-78\% of water level rise in a flood was caused by inflow from the river. Total inflow of four floods in 2006 was estimated about $1300 \mathrm{~mm}$, which was same amount of average annual precipitation. Hence, it's inferred that water exchange in floods contribute to material exchange and make influence for water quality in the floodplain.

Key words : floodplain, Lake Kasumigaura, water cycle, inundation, specific yield 